\title{
The Results of Radiological Screening in Asymptomatic At-Risk Members of Intracranial Aneurysm Families from the Turkish Population
}

\author{
Türk Popïlasyonundan Intrakraniyal Anevrizma Ailelerinde Risk \\ Altundaki Asemptomatik Bireylerin Radyolojik Tarama Sonuçlarn
}

Ethem GOKSU, Mahmut AKYUZ, Recai TUNCER

Akdeniz University, Faculty of Medicine, Department of Neurosurgery, Konyaalt, Antalya, Turkey

Correspondence address: Ethem GOKSU / E-mail: ethemgoksu@mynet.com

\begin{abstract}
AIM: To better understand the characteristics of familial intracranial aneurysms (FIA) and to investigate the yield of screening in asymptomatic, at-risk individuals in intracranial aneurysm (IA) families within the Turkish population.

MATERIAL and METHODS: We identified six families in which at least two first-degree relative members had an IA in our database. In five families, we screened 95 first-degree relatives of affected members.

RESULTS: As a result of our screening, we identified 9 unruptured aneurysms in 95 individuals for a total yield of $9.4 \%$. There was a prominent female preponderance in affected family members and nearly half of the aneurysms were on the middle cerebral artery (MCA). Most of the affected relatives were siblings.

CONCLUSION: Our results support a general recommendation to screen first-degree relatives of IA patients from families with two or more cases of IA. Familial aggregation of IA's is not only useful in identifying asymptomatic individuals harboring unruptured aneurysms but also implicates a genetic contribution to the pathogenesis of this disease in different patient populations.
\end{abstract}

KEYWORDS: Screening, Family, Intracranial aneurysm

Öz

AMAÇ: Ailesel intrakraniyal anevrizmaların niteliklerini daha iyi anlamak ve Türk popülasyonundan intrakraniyal anevrizma ailelerinde, risk altındaki asemptomatik bireylerin radyolojik taramasıyla elde edilecek sonuçları araştırmaktır.

YÖNTEM ve GEREÇ: Arşivimizden, birinci derece akrabalar arasında intrakraniyal anevrizmalı en az iki bireyin bulunduğu altı aile tespit ettik. Bunlardan beş tanesinde etkilenmiş bireylerin birinci derece yakını 95 ferde radyolojik tarama uyguladık.

BULGULAR: Tarama sonucunda 95 bireyin 9 tanesinde \%9,4'lük bir oranla anevrizma tespit edildi. Etkilenen aile bireyleri arasında belirgin bir kadın dominansı mevcuttu, anevrizmaların yarıya yakını orta serebral arter (MCA) yerleşimli idi ve çoğu etkilenen bireyler kardeşti.

SONUÇ: Sonuçlarımız, iki ve üzeri intrakraniyal anevrizmalı bireyin bulunduğu ailelerde birinci derece akrabaların taranmasına yönelik genel tavsiyeyi desteklemektedir. İntrakraniyal anevrizma ailelerinin toplanması, gerek ailedeki rüptüre olmamış anevrizmalı bireylerin tespitine imkan vermekte, gerekse de farklı hasta gruplarında hastalığın patogenezine dair genetik katkı sağlamaktadır.

ANAHTAR SÖZCÜKLER: Tarama, Aile, Intrakraniyal anevrizma

\section{INTRODUCTION}

In the absence of trauma, intracranial aneurysms (IA) are the leading cause of subarachnoid hemorrhage (SAH). Though rare compared to other types of stroke, SAH is the most devastating, resulting in more than $50 \%$ mortality (27). Among survivors, another $25 \%$ require a lifetime of care (27). Fortunately, the majority of IA's do not rupture. Thus, while 0.2 $-9.9 \%$ (mean $5 \%$ ) of the population is known to harbor an IA, the incidence of SAH is only 6 to 10 per 100,000 per year (11, $12,17,19,23,25,29)$.

IA is associated with known genetic disorders such as Autosomal Dominant Polycystic Kidney Disease and Ehlers-Danlos syndrome type IV $(3,16)$. However, these syndromes fall short of explaining the majority of familial IA cases, defined as two or more relatives with IA. Familial clustering of IA's has been documented since the 1960's, and the importance of heritable factors has been increasingly recognized. It is now known that in certain populations, first-degree relatives of patients with SAH from aneurysm rupture are four times more likely to harbor an IA $(14,18)$. The relative risk may be even greater in siblings, who have been reported to have a six-fold higher risk compared to the general population $(9,20,27)$. These findings, however, have not been replicated in other populations, making these results not universally applicable. 
The higher risk of IA formation and rupture among firstdegree relatives of aneurysmal SAH patients has prompted many clinicians to advocate screening in these family members. Two large trials have previously demonstrated that $10 \%$ of asymptomatic relatives of SAH patients harbor IA's $(11,21)$. Diagnostic studies and the following prophylactic interventions, however, are not without their inherent risks, which has lead to the debate as to whether it is ultimately in the benefit of this population to be screened. In order to better understand the yield of radiological screening in Turkish patient population, and to appreciate the characteristics of familial IA's in this patient population, we analyzed IA families with at least 2 affected members from our data.

\section{MATERIAL and METHODS}

\section{Family Identification}

We analyzed all the patients with IA in our database. In patients with positive family history of IA, stroke or cerebral hemorrhage, we established contact with the index cases and gathered clinical data by phone interview, or medical record review. A questionnaire was administered to index patient and other family members in terms of co-morbid medical problems, environmental risk factors, such as smoking and hypertension, and family history of connective tissue disorders.

Patients with familial IA's were defined by at least two firstdegree relative members (parents, siblings, and children) had an IA without any known heritable connective tissue disorder. Index cases were the first living person identified within a family who had a confirmed diagnosis of an IA. Family members were classified with affected, unaffected and suspected ones. Medical records documented an IA on angiogram, operative report or screening in affected members. In unaffected members, there was no supporting information for a possible IA. Patients with a clinically suspected aneurysmal SAH but without verification on imaging studies or at autopsy were designated as suspected. These families were documented with pedigrees.

This study protocol was approved by the local Ethics Committee at Akdeniz University School of Medicine. All of the family members who participated in the study signed informed consent forms. None of the families had any heritable disorder known to be associated with IA as part of the phenotype.

\section{Imaging Methodology:}

Magnetic resonance angiography (MRA) was performed by using a Siemens 1.5-T whole-body system (Magnetom Vision) with a $25-\mathrm{mT} / \mathrm{m}$ gradient capability. Spiral threedimensional computed tomographic angiography (3D-CTA) was conducted by a multi-helical system (Siemens Somatom Emotion) with a reconstruction index of 512 matrix and one second. Digital Subtraction Angiography (DSA) was performed via the femoral route with selective catheterization of the carotid and vertebral arteries. MRA was the initial screening procedure to first-degree relatives of affected members. In suspected cases, further evaluation was performed with CTA and DSA.

\section{Statistical Methods}

Mann-Whitney $U$ test and Fischer's exact test were used to evaluate the data and all analyses were with the SPSS 13.0 program.

\section{RESULTS}

We identified six families in which at least two members had an IA. Pedigrees of these six families are demonstrated in Figure 1A-F. In one family (family 6), no member was screened. In five families, we screened 95 asymptomatic individuals, aged 22 to 77 years (Table I). After the initial MRA screening, we found nine definite aneurysms in seven individuals and two individuals were identified as suspicious for IA. In these two subjects with suspected positive IA findings at MRA, DSA in one and 3D-CTA in the one subject were obtained in order to prove or disprove the MRA findings. DSA demonstrated two aneurysms in the locations suspected on MRA in this subject while 3D-CTA confirmed one aneurysm in one subject. Finally we detected 12 aneurysms in nine new affected members with a yield rate of $9.4 \%(9 / 95)$. The results of screening and the number of affected members in six families were summarized in Table II. Radiological views were shown in Figure 2A-H, 3A-D. There was a total of 25 affected members with 29 aneurysms in six families. The information about IA sizes and/or locations could not be obtained in three subjects. The mean age of these 25 members was 52.1. 13 of 29 aneurysms (45\%) were located on middle cerebral artery (MCA) and 6 of 25 subjects (24\%) had multiple aneurysms. All aneurysm locations were shown in Table III. All new affected members were female and among the entire group of affected relatives, the proportion of females and males was 18:7 (2.57). 10 ruptured aneurysms had a mean diameter of $5.9 \mathrm{~mm}(4-10$ $\mathrm{mm}, \mathrm{SD} \pm 2.34$ ), whereas the mean diameter was $4.53 \mathrm{~mm}$ in 15 unruptured aneurysms $(2-12 \mathrm{~mm}, \mathrm{SD} \pm 2.5)$. This difference

Table I: Number of Screened Members and ID in Families

\begin{tabular}{|c|c|l|}
$\begin{array}{c}\text { Family } \\
\text { no }\end{array}$ & $\begin{array}{c}\text { Number of } \\
\text { screened } \\
\text { members }\end{array}$ & Members ID in pedigrees \\
\hline 1 & 45 & $\begin{array}{l}\text { IV- } 2,4,6,10,12,13,21,23 \\
\text { V- (except19, 12-35), 37-39, 41-51 } \\
\text { III- (1-8) } \\
\text { IV- }(1-14),(16-20)\end{array}$ \\
\hline 2 & 27 & $\begin{array}{l}\text { II- } 1,8 \\
\text { III- 3, 4, 5, 7, 8, 9, 10 } \\
\text { IV- } 2\end{array}$ \\
\hline 3 & 10 & $\begin{array}{l}\text { IV- } 4,5,8 \\
\text { V- } 2,3,5,6,7,8 \\
\text { II- } 1,4,5,6\end{array}$ \\
\hline 4 & 9 & 95
\end{tabular}




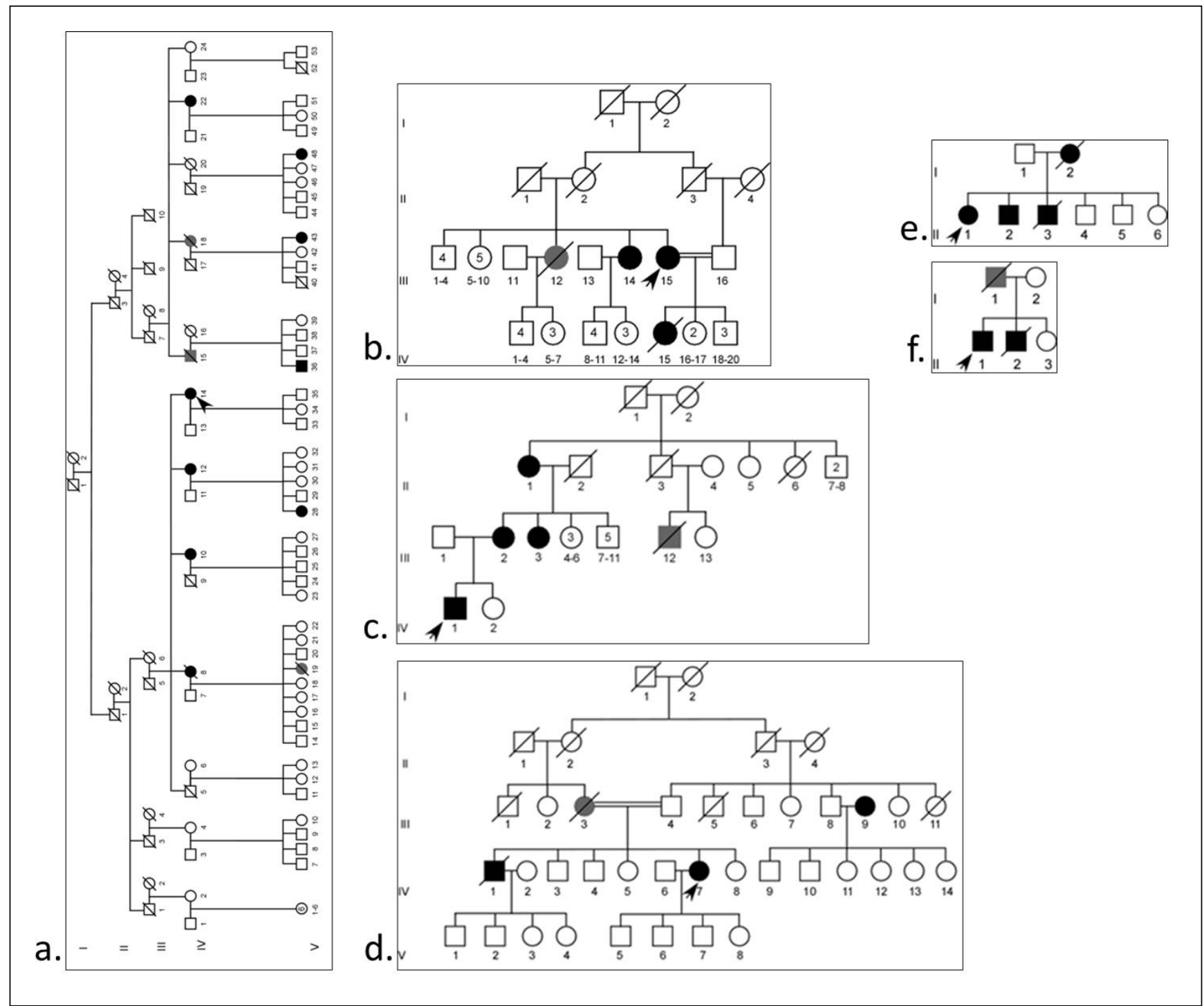

Figure 1: A) Pedigree of the family 1. Affected members were shown by a full blank circle or square and grey symbols describe members who died of a suspected SAH. Arrow shows the index case of this family (IV-14). B) Pedigree of the family 2. Affected members were shown by a full blank circle and grey symbol describes member who died of a suspected SAH. Arrow shows the index case of this family (III-15). C) Pedigree of the family 3. Affected members were shown by a full blank circle or square and grey symbol describes members who died of a suspected SAH. Arrow shows the index case of this family (IV-1). D) Pedigree of the family 4. Affected members were shown by a full blank circle or square and grey symbol describes member who died of a suspected SAH. Arrow shows the index case of this family (IV-7). E) Pedigree of the family 5. Affected members were shown by a full blank circle or square. Arrow shows the index case of this family (II-1). F) Pedigree of the family 6 . Affected members were shown by a full blank square and grey symbol describes member who died of a suspected SAH. Arrow shows the index case of this family (II-1).

was significant (Mann-Whitney $U$ test, $p=0.025$ ). The IA risk factor profile (hypertension and/or smoking) was found in 10 of 25 subjects (40\%). Eight of these 10 subjects had ruptured aneurysms whereas two of them had unruptured aneurysms. There was no significant difference in aneurysm rupture with risk factors (Fischer's exact test, $p=0.21$ ). Clinical features of all the affected members were presented in Table IV.

\section{DISCUSSION}

The familial occurrence of intracranial aneurysms was first documented by Chambers in 1954 (2). In 1980, Fox reported the largest family at the time consisting of 13 siblings, six of them had proven intracranial aneurysms and 2 of whom refused angiography (6). Since then, multiple families with IA have been reported in the literature. We are now reporting the results of radiological screening of at risk members in 5 families from the Turkish population. To our knowledge, one of these families (family 1 ) with 9 proven and 3 suspected affected members is one of the largest IA families in the literature. 
Table II: Number of Affected Members after Screening and Total in Families

\begin{tabular}{|c|c|c|c|c|}
\hline \multirow{2}{*}{ Family no } & \multirow{2}{*}{$\begin{array}{c}\text { Number of screened } \\
\text { members }\end{array}$} & \multirow{2}{*}{$\begin{array}{l}\text { Number of new affected } \\
\text { members after screening (\%) }\end{array}$} & \multicolumn{2}{|c|}{ Number of total affected members } \\
\hline & & & Proven & Suspected \\
\hline 1 & 45 & $6(13)$ & 9 & 3 \\
\hline 2 & 27 & - & 3 & 1 \\
\hline 3 & 10 & $2(20)$ & 4 & 1 \\
\hline 4 & 9 & - & 3 & 1 \\
\hline 5 & 4 & $1(25)$ & 4 & - \\
\hline Total & 95 & $9(9.4)$ & 23 & 6 \\
\hline
\end{tabular}
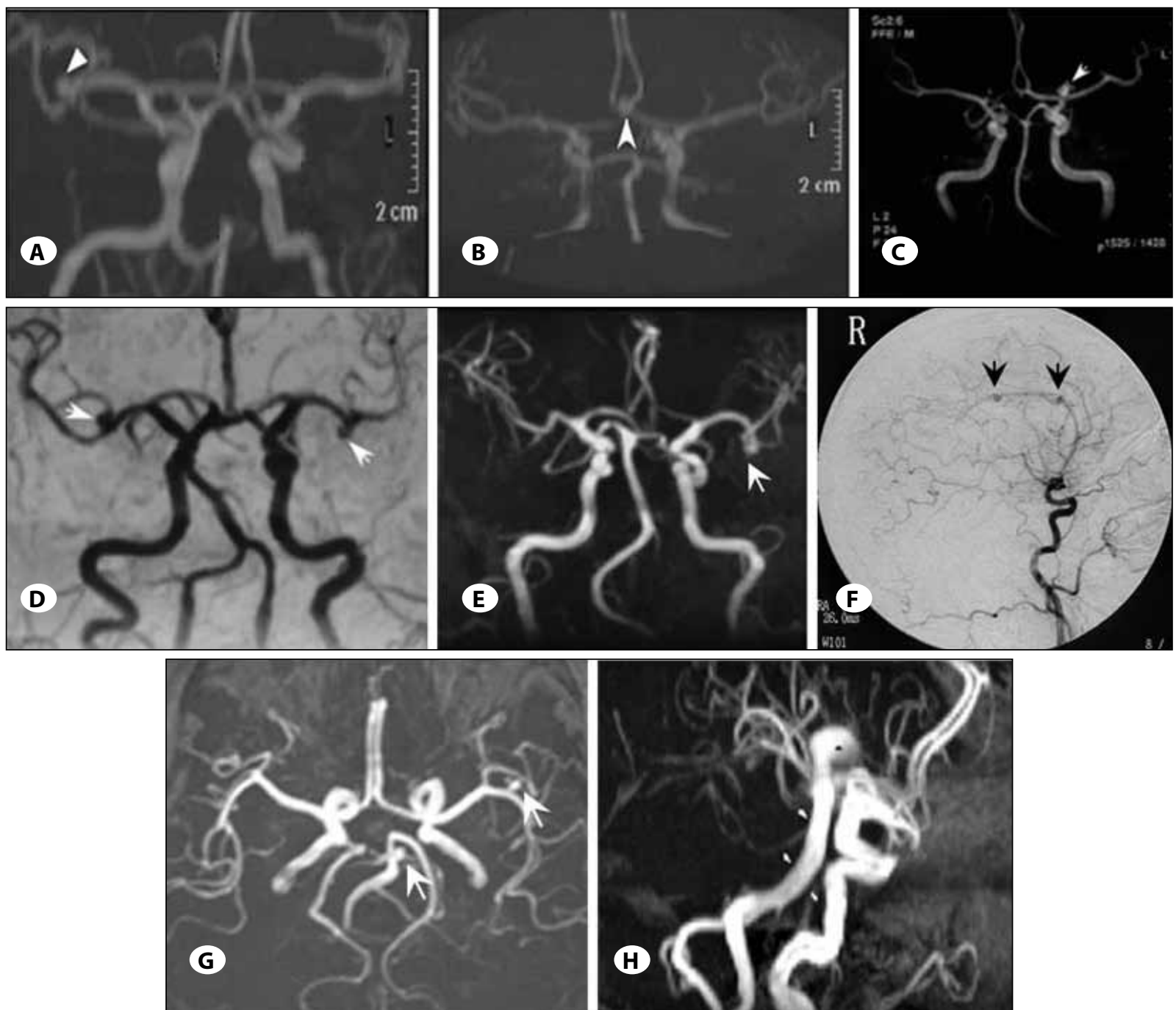

Figure 2: A) MRA maximum intensity projection (MIP) image in the frontal projection demonstrates a MCA bifurcation aneurysm on the right (arrow) (II-1 in family 3). B) MRA MIP image in the frontal projection demonstrates a AComA aneurysm (arrow) (III-3 in family 3). C) MRA MIP image in the frontal projection demonstrates an ICA bifurcation aneurysm on the left (arrow) (II-1 in family 5). D) MRA MIP image in the frontal projection demonstrates a MCA bifurcation aneurysm on the right (arrow), pointing laterally, and a left MCA bifurcation aneurysm pointing inferiorly and anteromedially (arrow) (IV-10 in family1). E) MRA MIP image in the frontal projection demonstrates a MCA bifurcation aneurysm on the left (arrow) (IV-12 in family 1). F) Lateral view of a left common carotid artery injection demonstrates two distal (pericallosal) ACA aneurysms (arrows) (V-43 in family 1). G) Base view MRA MIP image demonstrates a left MCA bifurcation aneurysm (arrow). In addition, there is an unusual aneurysm (arrow) arising at the $P_{1} P_{2}$ junction near the basilar summit pointing to the left and anteriorly (V-48 in family 1). H) MRA image in the lateral angiographic projection demonstrates a fusiformly dilated basilar artery (arrowheads) with a large saccular component at the basilar summit $\left(^{*}\right)($ IV-22 in family 1$)$. 

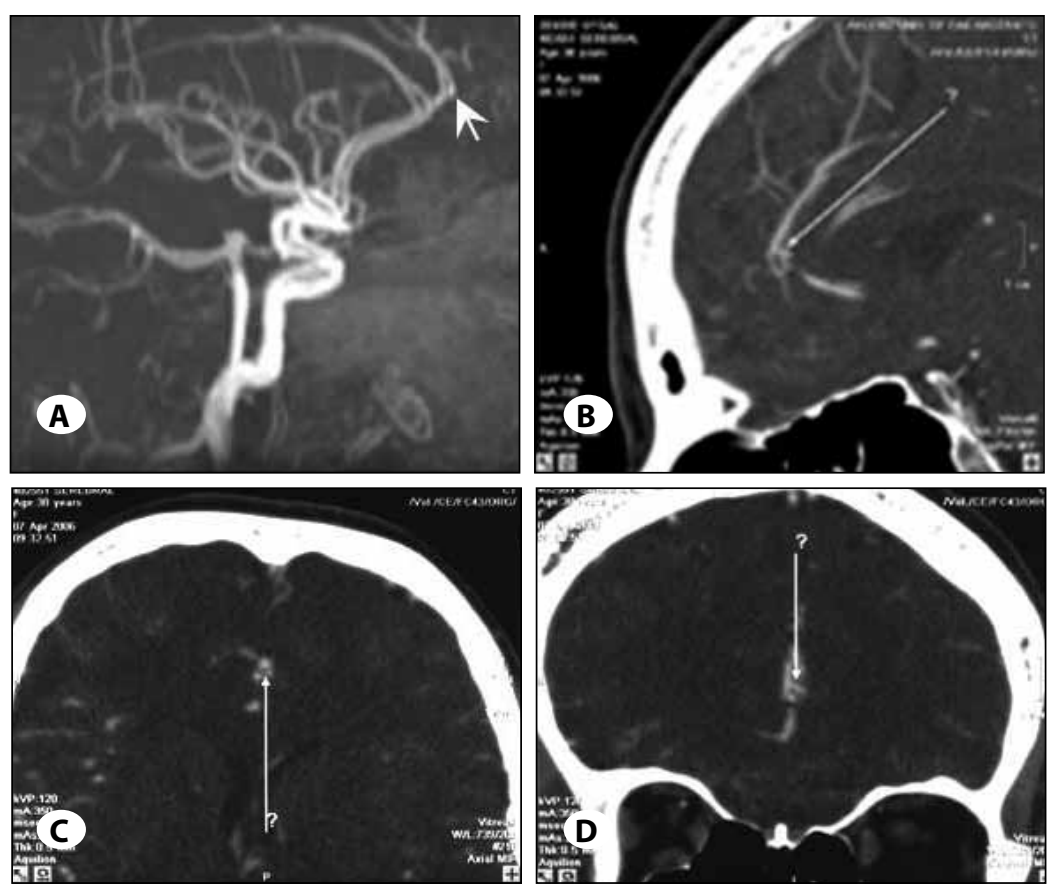

Figure 3: A) (MRA image in the lateral

angiographic projection),

B) (sagittal 2-D CTA),

C) (axial 2-D CTA),

D) (coronal 2-D CTA) demonstrates lobulated fullness of the pericallosal artery suggestive of a small bifurcation aneurysm (arrows) (V-28 in family 1).

Table III: Aneurysm Location and Number in all Affected Members

\begin{tabular}{|l|c|}
\hline Aneurysm location & Aneurysm number (\%) \\
\hline MCA & $13(45)$ \\
ACA & $9(30)$ \\
ICA & $4(13)$ \\
BA & $2(7)$ \\
PCA & $1(3)$ \\
\hline Total & 29 \\
\hline
\end{tabular}

MCA: middle cerebral artery, ACA: anterior cerebral artery, ICA: internal carotid artery, BA: basilar artery, PCA: posterior cerebral artery.

Persons with familial intracranial aneurysms represent 5-10\% of all patients presenting with aneurysmal SAH $(10,15,27)$. Familial aggregation of IA's may be useful in identifying asymptomatic individuals harboring unruptured aneurysms. Given the devastating consequences of an $\mathrm{SAH}$, detecting these IA's before they rupture is considered paramount. Radiological screening has been offered to susceptible individuals between the ages of 18 and 65 years in families with two or more affected members (26). This has also been recommended for children if a family member under 18 years of age has been diagnosed with an IA, and for persons with identical twins who have an IA (26). In the Finnish population, where the prevalence of SAH has been reported to be 4 times higher than other populations, approximately $10 \%$ of individuals are found to have an intracranial aneurysm (21, 22). In order to find the yield of screening in other populations and to understand whether this result is universally applicable, we radiographically screened five IA families in which at least two members had an IA from the Turkish population. Our data support previous guidelines as we have detected 9 new aneurysms in these five families by screening a total of 95 firstdegree family members for a total yield of $9.4 \%$. Furthermore, if all symptomatic members were encountered in five families, the IA prevalence could reach as high as $21 \%(23 / 110)$.

Affected members in IA families had a greater tendency to be female, smokers and hypertensive than the general population and their unaffected siblings (4). In our groups, $72 \%$ of affected family members (18/25) were female and $40 \%$ of them (10/25) were hypertensive and smokers. These findings may suggest the effects of these factors on the phenotypic expression of familial IA's. Smoking and size of the aneurysm are also important factors for aneurysm rupture (8). There was a significant difference in size between ruptured and unruptured aneurysms in our subjects. In six families, $60 \%$ of affected family members (15/25) were siblings, $45 \%$ of all IA (13/29) on MCA and $24 \%$ of subjects (5/25) had multiple IA. Female preponderance, relationships of affected relatives, IA location and multiplicity seemed to be consistent with the literature $(1,22)$.

MRA is currently the most widely used method for IA screening because of its relatively short imaging time and the noninvasiveness of the procedure. The majority of MRA screenings was performed without contrast although several of the patients in family 1 were screened with gadoliniumenhanced MRA. CTA screening adds the additional risks associated with ionizing radiation and iodinated contrast media reactions (24). MRA at its best is able to detect IA's as small as 2 or $3 \mathrm{~mm}$, but in prospective studies, the critical size for detection has been approximated at $4-5 \mathrm{~mm}(5,7,13)$. Spiral CTA, on the other hand, is reported to have $97 \%$ sensitivity and with good quality control can detect aneurysms as small 
Table IV: Clinical Features of all the Affected Members in Families

\begin{tabular}{|c|c|c|c|c|c|c|c|}
\hline Fam & ID & Age at diagnosis & Sex & SAH & Aneurysm location & Size $(\mathrm{mm})$ & Risk factor profile \\
\hline 1 & IV-8 & 61 & Female & + & AComA & 10 & - \\
\hline 1 & IV-10 & 62 & Female & - & $\begin{array}{c}\text { Bilateral } \\
\text { MCA }\end{array}$ & $\begin{array}{l}4 \\
5\end{array}$ & - \\
\hline 1 & IV-12 & 60 & Female & - & MCA & 5 & - \\
\hline 1 & IV-14 & 58 & Female & + & MCA & 6 & Hypertension \\
\hline 1 & IV-22 & 71 & Female & - & BA summit & 12 & Hypertension \\
\hline 1 & $V-28$ & 37 & Female & - & $\mathrm{ACA}-\mathrm{A}_{2}$ & 2 & - \\
\hline 1 & $V-36$ & 39 & Male & + & AComA & 6 & $\begin{array}{c}\text { Smoking } \\
\text { Hypertension }\end{array}$ \\
\hline 1 & $V-43$ & 44 & Female & - & $A C A-A_{2}(2)$ & 4 & - \\
\hline 1 & $V-48$ & 56 & Female & - & $\begin{array}{c}\text { MCA } \\
\text { PCA } \\
\left(P_{1}-P_{2}\right)\end{array}$ & $\begin{array}{l}3 \\
4\end{array}$ & - \\
\hline 2 & III-14 & 55 & Female & + & $\mathrm{ACA}-\mathrm{A}_{2}$ & $?$ & - \\
\hline 2 & III-15 & 68 & Female & + & ICA & 6 & Hypertension \\
\hline 2 & IV-15 & 42 & Female & + & BA bifurcation & $?$ & Hypertension \\
\hline 3 & II-1 & 69 & Female & - & MCA & 4 & Hypertension \\
\hline 3 & III-2 & 47 & Female & + & $\begin{array}{c}\text { MCA } \\
\text { ICA }\end{array}$ & $\begin{array}{l}3 \\
4\end{array}$ & - \\
\hline 3 & III-3 & 30 & Female & - & AComA & 4 & - \\
\hline 3 & IV-1 & 30 & Male & + & MCA (2) & 2,8 & Smoking \\
\hline 4 & III-9 & 65 & Female & + & AComA & 4 & - \\
\hline 4 & IV-1 & 49 & Male & + & MCA & 5 & \\
\hline 4 & IV-7 & 47 & Female & - & ICA & 8 & - \\
\hline 5 & $\mathrm{I}-1$ & 72 & Female & + & $?$ & $?$ & \\
\hline 5 & II-1 & 42 & Female & - & ICA & 4 & - \\
\hline 5 & II-2 & 39 & Male & + & MCA (2) & $?$ & - \\
\hline 5 & II-3 & 45 & Male & + & $?$ & $?$ & Smoking \\
\hline 6 & II-1 & 55 & Male & + & $\mathrm{MCA}$ & 6 & Hypertension \\
\hline 6 & $\| I-2$ & 60 & Male & + & AComA & 4 & Smoking \\
\hline
\end{tabular}

Fam: Family, SAH: Subarachnoid hemorrhage, AComA: Anterior communicating artery, MCA: Middle cerebral artery, BA: Basilar artery, ACA: Anterior cerebral artery, ICA: Internal carotid artery.

as $2 \mathrm{~mm}$ (28). The ability of CTA images to be reconstructed with both 2-D and 3-D algorithms allows better anatomical delineation of the aneurysms, reproducible aneurysm measurements, and may increase the diagnostic accuracy (30). The post processing procedures are considerably more labor intensive than standard non-contrast time of flight MRA imaging (30).

Our data prove MRA as an effective initial screening modality followed by confirmation with CTA or DSA in equivocal cases. This method enabled us to detect nine definite IA's using MRA alone, followed by confirmation of two aneurysms suspected by CTA or DSA. The quality of the images and the experience of the radiologist in the interpretation of vascular images are the most important factors in the non-invasive imaging detection of IA's.
Although a small sample size was studied, the cumulative results (not in every family) extended the previous large Finnish and Japanese population findings. We only identified six familial subjects in our 700 IA patients. This ratio does not reflect the 5- $10 \%$ incidence of familial IA's. In order to find more realistic results, a more detailed questionnaire should be administered and more screening procedures should be applied. One of our families with 9 proven and 3 suspected affected members seems to be a candidate of the largest IA family in the world. We estimate that there are many familial subjects in the Turkish population because of consanguineous marriages, and large family traditions in specific regions. The cooperative studies may help the collection of Turkish familial IA database. 
Furthermore, familial aggregation of IA's also implicates a genetic contribution to the pathogenesis of this disease in different patient populations. Using an approach with genome-wide linkage analysis of large kindreds, in which inheritance of IA follows a simple Mendelian pattern, may be useful in identifying IA susceptibility loci. Identification of IA susceptibility loci will not only allow early preclinical diagnosis but will also shed light into basic disease mechanisms that will ultimately lead to novel treatment of this deadly disease.

\section{ACKNOWLEDGEMENT}

We deeply thank Dr. Murat Günel (Yale University Neurovascular Surgery Programme, CT/USA) for his financial support to radiological screening of family members.

\section{REFERENCES}

1. Bromberg JE, Rinkel GJ, Algra A, van Duyn CM, Greebe P, Ramos LM, van Gijn J: Familial subarachnoid hemorrhage: Distinctive features and patterns of inheritance. Ann Neurol 38:929-934, 1995

2. Chambers WR, Harper BF, Simpson JR: Familial incidence of congenital aneurysms of cerebral arteries: Report of cases of ruptured aneurysms in father and son. J Am Med Assoc 155:358-359, 1954

3. Chapman $A B$, Rubinstein $D$, Hughes R, Stears JC, Earnest MP, Johnson AM, Gabow PA, Kaehny WD: Intracranial aneurysms in autosomal dominant polycystic kidney disease. $\mathrm{N}$ Engl J Med 327:916-920, 1992

4. Connolly ES Jr, Choudhri TF, Mack WJ, Mocco J, Spinks TJ, Slosberg J, Lin T, Huang J, Solomon RA: Influence of smoking, hypertension, and sex on the phenotypic expression of familial intracranial aneurysms in siblings. Neurosurgery 48:64-68; discussion 68-69, 2001

5. Falk A, Schmieder K, Hentsch A, Harders A, Heuser L: 3-D-TONE magnetic resonance angiography in the detection of intracranial aneurysms compared with digital subtraction angiography. A prospective study. Rofo 164:31-37, 1996

6. Fox JL, Ko JP: Familial intracranial aneurysms. Six cases among 13 siblings. J Neurosurg 52:501-503, 1980

7. Huston J, 3rd, Nichols DA, Luetmer PH, Goodwin JT, Meyer FB, Wiebers DO, Weaver AL: Blinded prospective evaluation of sensitivity of $M R$ angiography to known intracranial aneurysms: Importance of aneurysm size. AJNR Am J Neuroradiol 15:1607-1614, 1994

8. Juvela S, Porras M, Poussa K: Natural history of unruptured intracranial aneurysms: Probability of and risk factors for aneurysm rupture. J Neurosurg 93:379-387, 2000

9. Kasuya H, Onda H, Takeshita M, Hori T, Takakura K: Clinical features of intracranial aneurysms in siblings. Neurosurgery 46:1301-1305, discussion 1305-1306, 2000

10. Kissela BM, Sauerbeck L, Woo D, Khoury J, Carrozzella J, Pancioli A, Jauch E, Moomaw CJ, Shukla R, Gebel J, Fontaine $\mathrm{R}$, Broderick J: Subarachnoid hemorrhage: A preventable disease with a heritable component. Stroke 33:1321-1326, 2002

11. Kojima M, Nagasawa S, Lee YE, Takeichi Y, Tsuda E, Mabuchi $\mathrm{N}$ : Asymptomatic familial cerebral aneurysms. Neurosurgery 43:776-781, 1998

12. Kongable GL, Lanzino G, Germanson TP, Truskowski LL, Alves WM, Torner JC, Kassell NF: Gender-related differences in aneurysmal subarachnoid hemorrhage. J Neurosurg 84: 43-48, 1996

13. Korogi Y, Takahashi M, Mabuchi N, Miki H, Fujiwara S, Horikawa Y, Nakagawa T, O'Uchi T, Watabe T, Shiga H, et al: Intracranial aneurysms: Diagnostic accuracy of three-dimensional, Fourier transform, time-of-flight MR angiography. Radiology 193:181-186, 1994

14. Leblanc R: The risk of intracranial aneurysms in families with subarachnoid hemorrhage. Can J Neurol Sci 22:333, 1995

15. Lozano AM, Leblanc R: Familial intracranial aneurysms. J Neurosurg 66:522-528, 1987

16. Nekrysh SY: Association between heritable connective tissue disorders and intracranial aneurysms. Surg Neurol 54:77-78, 2000

17. Pakarinen S: Incidence, aetiology, and prognosis of primary subarachnoid haemorrhage. A study based on 589 cases diagnosed in a defined urban population during a defined period. Acta Neurol Scand 43(29):1-28, 1967

18. Raaymakers TW: Aneurysms in relatives of patients with subarachnoid hemorrhage: Frequency and risk factors. MARS Study Group. Magnetic resonance angiography in relatives of patients with Subarachnoid hemorrhage. Neurology 53:982988, 1999

19. Rinkel GJ, Djibuti M, Algra A, van Gijn J: Prevalence and risk of rupture of intracranial aneurysms: A systematic review. Stroke 29:251-256, 1998

20. Ronkainen A, Hernesniemi J, Puranen M, Niemitukia L, Vanninen R, Ryynanen M, Kuivaniemi H, Tromp G: Familial intracranial aneurysms. Lancet 349:380-384, 1997

21. Ronkainen A, Hernesniemi J, Ryynanen M: Familial subarachnoid hemorrhage in east Finland, 1977-1990. Neurosurgery 33:787-796; discussion 796-797, 1993

22. Ronkainen A, Hernesniemi J, Tromp G: Special features of familial intracranial aneurysms: Report of 215 familial aneurysms. Neurosurgery 37:43-46, discussion 46-47, 1995

23. Ronkainen A, Miettinen $H$, Karkola K, Papinaho S, Vanninen $R$, Puranen $M$, Hernesniemi J: Risk of harboring an unruptured intracranial aneurysm. Stroke 29:359-362, 1998

24. Ronkainen A, Puranen MI, Hernesniemi JA, Vanninen RL, Partanen PL, Saari JT, Vainio PA, Ryynanen M: Intracranial aneurysms: MR angiographic screening in 400 asymptomatic individuals with increased familial risk. Radiology 195:35-40, 1995

25. Schievink WI: Intracranial aneurysms. N Engl J Med 336:28-40, 1997

26. Schievink WI: Genetics and aneurysm formation. Neurosurg Clin N Am 9:485-495, 1998

27. Schievink WI, Schaid DJ, Michels VV, Piepgras DG: Familial aneurysmal subarachnoid hemorrhage: A community-based study. J Neurosurg 83:426-429, 1995

28. Tipper G, U-King-Im JM, Price SJ, Trivedi RA, Cross JJ, Higgins NJ, Farmer R, Wat J, Kirollos R, Kirkpatrick PJ, Antoun NM, Gillard JH: Detection and evaluation of intracranial aneurysms with 16-row multislice CT angiography. Clin Radiol 60:565572,2005

29. Winn HR, Jane JA Sr, Taylor J, Kaiser D, Britz GW: Prevalence of asymptomatic incidental aneurysms: Review of 4568 arteriograms. J Neurosurg 96:43-49, 2002

30. Young G, Humphrey P: Clinical carotid endarterectomy decision-making: Noninvasive vascular imaging versus angiography. Neurology 57:2324, 2001 